\title{
Co-Design and Trust in Social Network's Websites
}

\author{
Jyh-Jeng Wu', Shu-Hua Chien'2, Khash-Orgil Gansukh'1, Xin-Jiao Yang1 \\ ${ }^{1}$ Department of Business Management, National United University, \\ Taiwan \\ ${ }^{2}$ Department of Insurance and Finance, National Taichung University of Science and Technology, \\ Taiwan \\ Email: jjwu@nuu.edu.tw, chien9149@nutc.edu.tw, jj141001@gmail.com, a0930966728@gmail.com
}

Received 11 May 2016; accepted 2 July 2016; published 5 July 2016

Copyright (C) 2016 by authors and Scientific Research Publishing Inc.

This work is licensed under the Creative Commons Attribution International License (CC BY).

http://creativecommons.org/licenses/by/4.0/

(c) () Open Access

\begin{abstract}
This research is focused on internet shoppers co-design, individual tendency of trust, trust belief, and purchase intention. An online questionnaire was set out in survey form on Google Docs in order to collect data. The survey was conducted of participants in Mongolia. 236 usable responses were obtained from Mongolian potential customers in order to examine constructs. The findings suggest that co-design and individual tendency of trust have significant positive effect on the trust levels throughout intention to purchase.
\end{abstract}

\section{Keywords}

\section{Co-Design, Trust, Purchase Intention}

\section{Introduction}

Recently, there has been still growing interest in an online environment over the world. The usage of the internet tends to increase year by year. Since 2000, 360,985,492 users were reported by Internet World Stats; moreover, the usage of Internet users has increased by $566.4 \%$ to $2,405,518,376$ users by the end of 2012 [1]. Market of online shopping is hoisted constantly due to the high population of the Internet users. Mongolia is one of the countries that have experienced a high GDP growth rate in the economy. In particular, the GDP growth rate went to 18.1\% in 2013, ranked at first among other economies (Top Growers economist.com). Due to the higher growth rates, Mongolia has attracted many international investors and firms. 


\section{Literature Review}

\subsection{Mongolian Internet Environment}

Mongolian 1990's peaceful democratic revolution, the science technology was carried on to develop at a whole new level. After the democratic evolution, internet was established in 1995. Since 2009, there have been introduced e-postal services, e.g. Post-SMS through https://postnews.mn/, Tourist center and e-Post, a digital postdelivery box. As a consequence of these services, citizens and travelers are able timely to receive information on parcels, and other postal activities through e-mail and SMS. Mongolia is the most sparsely populated independent country in the world. It is a serious constraint to countrywide Internet deployment, but International Telecommunications Union reported, in 2012, usage of internet is over 16.4\% (521,520 users) of the population.

As can be seen from Figure 1 and Figure 2, the social network's popularity among Mongolian, including: Facebook, Twitter, YouTube, Biznetwork, Instagram, Viber. Population of Facebook is increased in end of the 2013 by 598,000. According to an analytical report, a usage rate of Facebook is significantly dominated 68.9\% of the Mongolian users between the age of 18 - 35. With respect to the information, People of Mongolian usage of the internet tend to increase as an internet environment develops.

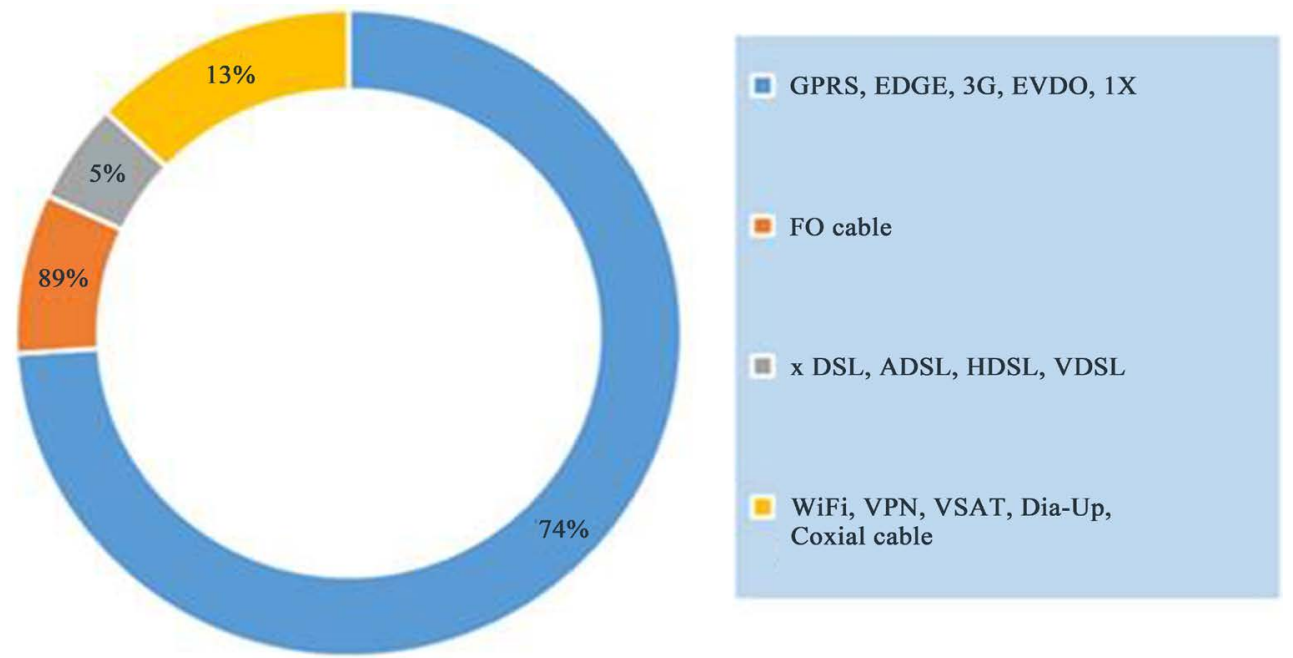

Figure 1. Types of Internet connectivity usage by types source: white paper on ICT development, Mongolia-2013.

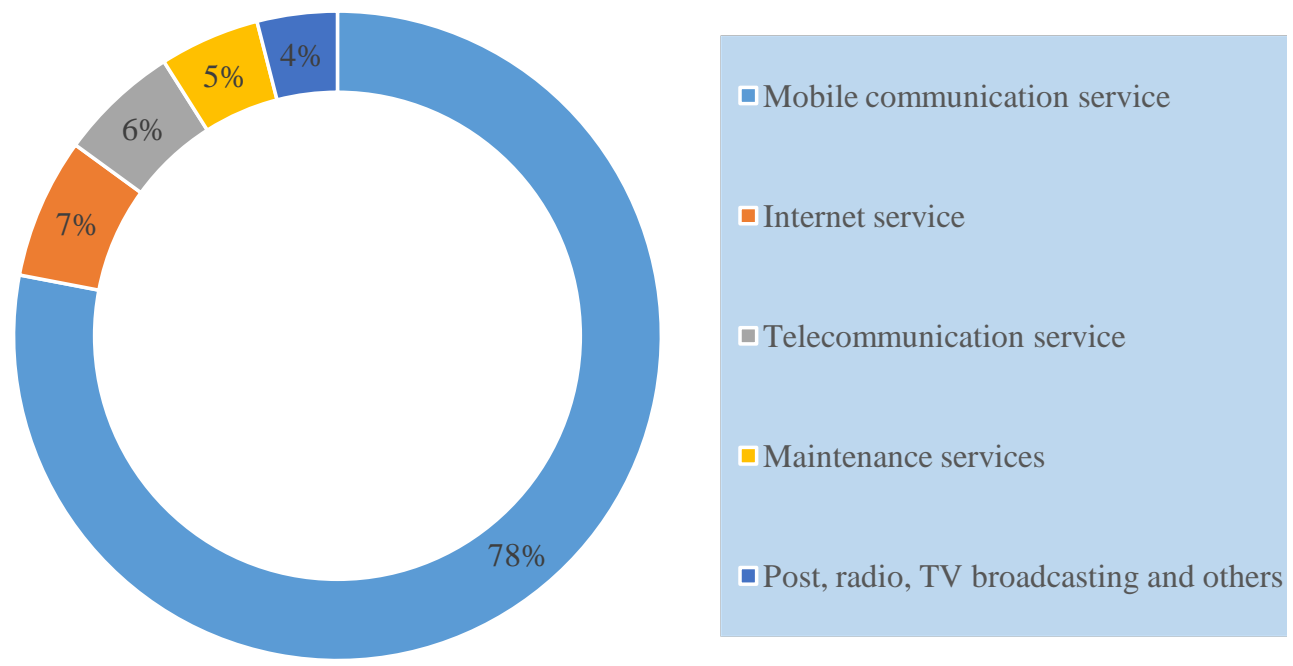

Figure 2. The total revenue and service types of ICT sector, by percentages source: white paper on ICT development, Mongolia-2013. 


\subsection{Co-Design}

Authors who have tackled the theme of co-design include Penaloza and Venkatesh [2] who, in their writings, ascribe social construction to the active role of the consumer, in the sense that it enriches the products with meanings and symbolisms by their participation to design. By co-design Sanders and Stappers [3] indicate collective creativity as it is applied across the whole span of a design process.

\subsection{Individual Tendency of Trust}

Individual tendency of trust represents the internal traits that drive the individual behavior tendency to trust [4]. Individual tendency is important to the extent that it determines if one believes that nonspecific individuals or institutions are trustworthy. McKnight, and Chervany (1998) refers individual tendency of trust as the reliance of the trustee before the relationship is developed. Whitener, Brodt, Korsgaard, and Werner [5] suggest that the individual tendency to trust is a critical factor influencing the initial trusting formation when the information is incomplete. The high individual tendency to trust implies a positive personal trait to embrace wide spectrum of humanity and be more open to new situations and experiences. Individuals with a high tendency tend to develop trust toward the website from the initial contact (Moorman, Rohit, and Gerald, 2002).

\subsection{Trust Belief}

Trust refers to when an individual person feeling assurance while experiencing vulnerable, uncertain, or risky circumstances [6] [7]. In the online market relationship, a consumer/customer represents the trustor and a retailer represents the trustee [8]. Mayer, Davis, and Schoorman [8] distinguished between trust and trustworthiness, with trustworthiness being antecedent to and driving trustors' levels of trust placed in the trustee. Mayer, Davis, and Schoorman [8] determined that there are three prime factors of trustworthiness: benevolence, integrity, and ability.

\subsection{Purchase Intention}

A great deal of recent research has demonstrated that greater trust is associated with stronger purchase intention [9] [10]. On the other hand, without trust, it is barely possible to persuade consumer to persuade them that the brand is worthy to purchase. In today's market buyers have a great deal of choices from which to select [11]. Therefore, co-design affects purchase intention as a function of the way that it invokes trust of a brand. Finally, existing studies show that trust affects relationship commitment [12]. When a consumer has a higher degree of trust to the seller, the consumer will elicit higher degree of purchase intentions [13] [14]. If a consumer trusts online store, the consumer is likely to form a positive intention to purchase. When customers believe they are capable of performing a task, they will be more likely to engage in that behavior [15]. Similarly, as a co-designer role clarity in participation increases, customers will enhance their understanding of role requirements and be more likely to participate in future intention [16]. Such engagement in the product or service will influence purchase intention.

\section{Research Method}

\subsection{Theoretical Method}

The research model of this study is shown in Figure 3. As shown in the research model, there are four major construct in this study: co-design, individual tendency of trust, trust belief, and purchase intention.

\subsection{Research Hypotheses}

Hypothesis 1: Individual tendency of trust influences trust belief positively.

Hypothesis 2: Co-design influences customers' trust belief positively.

Hypothesis 3: Trust belief is a mediator for co-design, individual tendency of trust and purchase intention.

H3a: Trust belief is a mediator between co-design and purchase intention.

H3b: Trust belief is a mediator between individual tendency of trust and purchase intention.

\subsection{Measurement of Variables}

The questionnaire classified into 24 questions of six sections: "co-design (8 items)”, "individual tendency of trust 
H3a

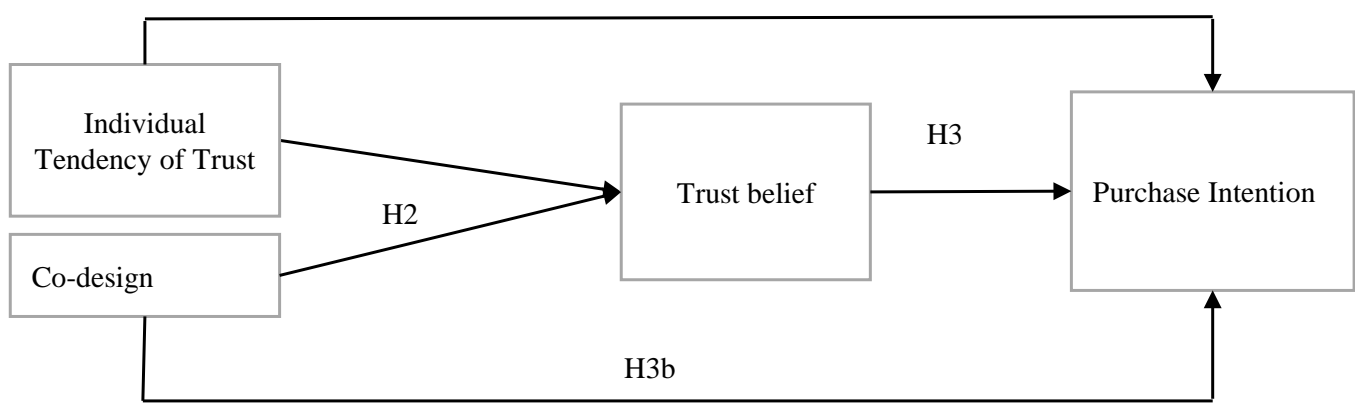

Figure 3. Research model.

(4 items)", "trust belief (4 items)", and "purchase intention (3 items)". Furthermore, demographic information is included in questionnaire with 5 items gender, age, online purchase experience, brand preference, and average purchase amount. In order to collect data from Mongolian potential buyers, the survey was written in English and translated into Mongolia.

\subsection{Research Sampling and Data Collection}

A positivist research design is an established method to evaluate the relationships between constructs. Cresswell [17] suggests a positivist research design is appropriate when the aim of the investigation is to discover levels of the independent constructs may have effect on the dependent constructs.

An online questionnaire was set out in survey form on Google Docs in order to collect data. The survey was took from participants in Mongolia and the data was collected between April to May 2014. Before we took the survey, to make ensure co-design experience which means convince them to knowledge about Nike ID online platform. The questions were arranged in multi-choice scales to ensure accurate response of the consumers. Each scale consisted of several questions related to the constructs; the answers to the questions were averaged to arrive at scale score. The questions were asked in Likert scales which have measurable values indicates between strongly disagree and indicates strongly agree with one to five. Totally, 236 usable responses were obtained from participants.

\section{Data Analysis and Research Result}

This chapter will cover research subject, data analysis regarding to the valid questionnaires.

\subsection{Descriptive Analysis of Demographic Information}

Demographic information is described. Five major items were included in this research: (i) Gender, (ii) Age, (iii) Online shopping experience, (iv) Online store preference, (v) Average amount of the per purchase.

Gender is demonstrated as 75 (38.7\%) male and 119 (61.3\%) female participants of the valid responses. Moreover, more than 158 (81.7) participants were aged 18 to 25 years old, 21 (10.8\%) participants are 26 to 30 years old and 15 (7.7\%) were aged above 31 years old. With regard to preference of online shopping from the popular shops in Mongolia, i.e. Ebay.com 64 (21\%), Amazon.com 79 (25\%), Alibaba.com 10 (3\%), Mongolian online shops and Others are $61(19 \%)$. There are over $65 \%$ of respondents were purchasing from the online shop is more than a year. Over $60 \%$ the participated consumers appear to mostly spend 50 US\$ - 200 US\$ on each purchase on their apparel product. The participants mostly prefer brands Zara, H\&M, Forever 21, Uniqlo, and Nike, Adidas from others.

\subsection{Descriptive Analysis of Likert Scaled Questions}

In co-design construct, all of eight items above 3.43 which means the mean value was tend positive scale of measurement. Another four items of construct individual tendency of trust are averaged above 3 mean value. The questions are remarkably agreed by a participant. On the other hand, which means participant has a tendency to develop trust toward the retailer. 


\subsection{Hypothesis Testing and Regression Analysis}

The following suggestions of Baron and Kenny [18] three conditions must be verified in order to prove the effect: (1) the independent variables must be significantly related to mediate variable; (2) the mediate variable must be significantly related to the dependent variable; and (3) when the mediate variable is involved, the independent variables should not be significantly related to or have a lesser effect on the mediate variable.

The results of main and mediator effect analysis are provided in Table 1. Variance Inflation Factor (VIF) values are below 2 across all models, which meet the standards of Hair, Anderson, Tatham, and Black [19], who suggested a VIF of less than 10 as the measurement for collinearity. In other word, multi-collinearity does not exist. As such, the regression model is appropriate. With regards to Table 1 all independent variables significantly effects with the dependent variables. Firstly, the Model 1 is to investigate the mediate effect of co-design and trust belief on purchase intention. Secondly, Model 2 is to test whether the mediate effect of individual tendency of trust and trust belief on purchase intention. Co-design has a significant influence Trust belief is described in Model 1, which is also supporting the Hypothesis 1 with $\left(\mathrm{R}^{2}\right.$ 0.509). Model 2 describes Individual Tendency of Trust has effect on Trust belief, since coefficient value $\left(0.714^{* * *}\right)$ and R2. It is supporting the Hypothesis 2. As result of Model 7, Trust belief has significantly effect on Purchase intention for Hypothesis 3. On the same time, we compare the final results of hypotheses in Table 2.

\section{Conclusion}

Firstly, the suggestion is trust tendency influence positively toward trusting belief. In addition, when individual trust tendency increases, the buyers have tendency to increase their trust level to the retailer company. Thus, Hypothesis 1 is supported. As a result for Hypothesis 2 is supported, co-design is positive effects to trust beliefs. If a customer allows higher participation in co-design with the company, it appears to have more trust from

Table 1. Results of regression analysis $(\mathrm{N}=236)$.

\begin{tabular}{|c|c|c|c|c|c|c|c|}
\hline Dependent variable & \multicolumn{2}{|c|}{ Trust belief } & \multicolumn{5}{|c|}{ Purchase intention } \\
\hline Independent variable & \multicolumn{7}{|c|}{ Standardized regression coefficients ( $\beta$ value) } \\
\hline Regression model & Model 1 & Model 2 & Model 3 & Model 4 & Model 5 & Model 6 & Model 7 \\
\hline Co-design & $0.722^{* * *}$ & & $0.290 * * *$ & & $0.638 * * *$ & & \\
\hline Individual tendency of trust & & $0.714^{* * *}$ & & $0.214^{* * *}$ & & $0.598 * * *$ & \\
\hline Trust belief & & & $0.482 * * *$ & $0.539 * * *$ & & & $0.691 * * *$ \\
\hline $\mathrm{R}^{2}$ & 0.521 & 0.509 & 0.518 & 0.500 & 0.407 & 0.358 & 0.478 \\
\hline Adjusted $\mathrm{R}^{2}$ & 0.519 & 0.507 & 0.514 & 0.498 & 0.404 & 0.355 & 0.476 \\
\hline F value & $254.116^{* * *}$ & $242.751^{* * *}$ & $125.196 * * *$ & $116.558^{* * *}$ & $160.301^{* * *}$ & $130.269 * * *$ & $214.060^{* * *}$ \\
\hline $\mathrm{t}$ value & $15.941^{* * *}$ & $15.580^{* * *}$ & $\begin{array}{l}4.410 * * * \\
7.340 * * *\end{array}$ & $\begin{array}{l}3.230 * * * \\
8.150 * * *\end{array}$ & $12.661^{* * *}$ & $11.414^{* * *}$ & $14.631^{* * *}$ \\
\hline
\end{tabular}

${ }^{*} \mathrm{p}=<0.05 ; * *=\mathrm{p}<0.01 ; * * *=\mathrm{p}<0.001$

Table 2. Results of hypotheses.

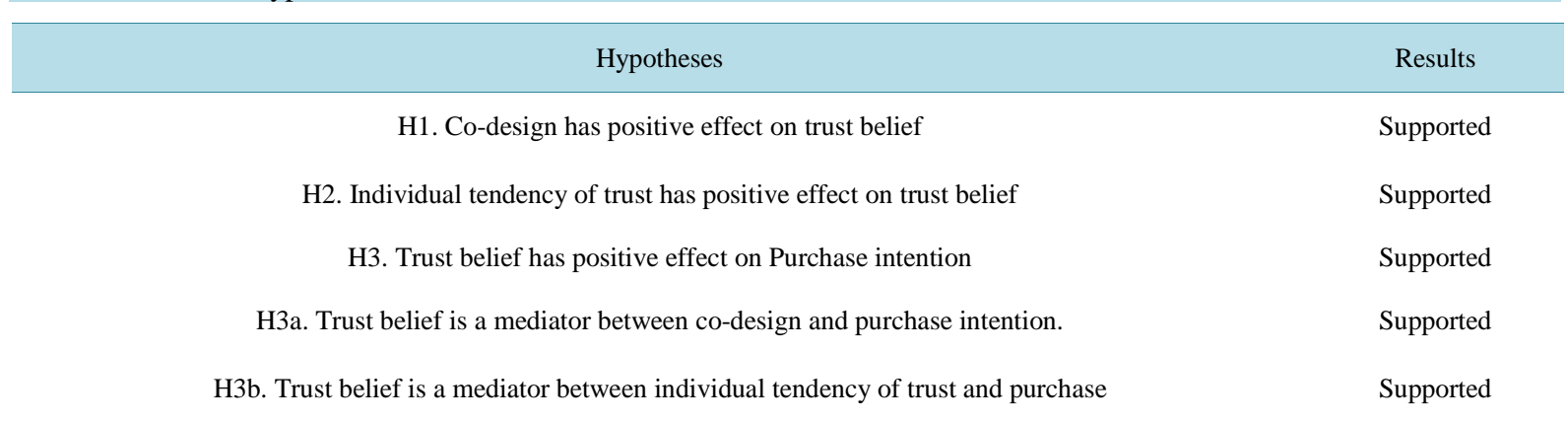


consumers. Hypothesis 3 is supported by having the higher trust degree that significantly affects intention to purchase. For the H3a and H3b mediating effect, trust belief has partially mediated with individual tendency of trust, co-design and purchase intention. Thus, all of the hypotheses and mediator have supported.

\section{Limitations and Future Research}

Limitation of this study is that data collected from young age groups, ages between 18 and 30 . The suggestion for the future study is researcher not just focus on Mongolian consumers, also it could be focused on other countries. Latterly, companies use a co-design, and it is a fairly new concept and new trend in customer-centric marketing. For instance, those companies related to co-design platform who allows customers to customize their chosen products. Therefore, research also could be focus on impact of consumers' relationship, satisfaction, Word of Mouth, service quality and other consumers' behaviors.

\section{References}

[1] (2013) Percentage of Individuals Using the Internet 2000-2012. International Telecommunications Union, Geneva.

[2] Penaloza, L. and Venkatesh, A. (2006) Further Evolving the New Dominant Logic of Marketing: From Services to the Social Construction of Markets. Marketing Theory, 6, 299-316. http://dx.doi.org/10.1177/1470593106066789

[3] Sanders, E.B.N. and Stappers, P.J. (2008) Co-Creation and the New Landscapes of Design. Co-Design, 4, 5-18. http://dx.doi.org/10.1080/15710880701875068

[4] Chen, Y.H., Wu, J.J. and Chung, Y.S. (2008) Cultural Impact on Trust: A Comparison of Virtual Communities in China, Hong Kong, and Taiwan. Journal of Global Information Technology Management, 11, 28-48. http://dx.doi.org/10.1080/1097198X.2008.10856460

[5] Whitener, E.M., Brodt, S.E., Korsgaard, M.A. and Werner, J.M. (1999) Managers as Initiators of Trust: An Exchange Relationship Framework for Understanding Managerial Trustworthy Behavior. Academy of Management Review, 23, 513-530.

[6] McKnight, D.H. and Chervany, N.L. (2002) What Trust Means in E-Commerce Customer Relationships: An Interdisciplinary Conceptual Typology. International Journal of Electronic Commerce, 6, 35-60.

[7] Denize, S. and Young, L. (2007) Concerning Trust and Information. Industrial Marketing Management, 36, 968-982. http://dx.doi.org/10.1016/j.indmarman.2007.06.004

[8] Mayer, R.C., Davis, J.H. and Schoorman, F.D. (1995) An Integrative Model of Organizational Trust. Academy of Management Review, 20, 709-734.

[9] Zhu, D.S., Lee, Z.C.R. and O’Neal, G.S. (2011) Mr. Risk! Please Trust Me: Trust Antecedents That Increase Online Consumer Purchase Intention. Journal of Internet Banking \& Commerce, 16, No. 3.

[10] Kim, J.B. (2012) An Empirical Study on Consumer First Purchase Intention in Online Shopping: Integrating Initial Trust and TAM. Electronic Commerce Research, 12, 125-150. http://dx.doi.org/10.1007/s10660-012-9089-5

[11] Herbst, K.C., Hannah, S.T. and Allan, D. (2013) Advertisement Disclaimer Speed and Corporate Social Responsibility: "Costs" to Consumer Comprehension and Effects on Brand Trust and Purchase Intention. Journal of Business Ethics, 117, 297-311. http://dx.doi.org/10.1007/s10551-012-1499-8

[12] Morgan, R.M. and Hunt, S.D. (1994) The Commitment-Trust Theory of Relationship Marketing. Journal of Marketing, 58, No. 3. http://dx.doi.org/10.2307/1252308

[13] Jarvenpaa, S.L. and Tractinsky, N. (1999) Consumer Trust in an Internet Store: A Cross-Cultural Validation. Journal of Computer Mediated Communication, 5, 1-35. http://dx.doi.org/10.1111/j.1083-6101.1999.tb00337.x

[14] Gefen, D. and Straub, D.W. (2004) Consumer Trust in B2C E-Commerce and the Importance of Social Presence: Experiments in E-Products and E-Services. Omega, 32, 407-424. http://dx.doi.org/10.1016/j.omega.2004.01.006

[15] Seltzer, L.F. (1983) Influencing the "Shape” of Resistance: An Experimental Exploration of Paradoxical Directives and Psychological Reactance. Basic and Applied Social Psychology, 4, 47-71. http://dx.doi.org/10.1207/s15324834basp0401_5

[16] Meuter, M.L., Bitner, M.J., Ostrom, A.L. and Brown, S.W. (2005) Choosing among Alternative Service Delivery Modes: An Investigation of Customer Trial of Self-Service Technologies. Journal of Marketing, 69, 61-83. http://dx.doi.org/10.1509/jmkg.69.2.61.60759

[17] Creswell, J.W. (2009) Research Design: Qualitative, Quantitative, and Mixed Methods Approaches. Sage Publications, Inc.

[18] Baron, R.M. and Kenny, D.A. (1986) The Moderator-Mediator Variable Distinction in Social Psychological Research: 
Conceptual, Strategic, and Statistical Considerations. Journal of Personality and Social Psychology, 51, 1173. http://dx.doi.org/10.1037/0022-3514.51.6.1173

[19] Hair, J.F., Anderson, R.E., Tatham, R.L. and Black, W.C. (1998) Multivariate Analysis. Prentice Hall International, Englewood.

Submit or recommend next manuscript to SCIRP and we will provide best service for you:

Accepting pre-submission inquiries through Email, Facebook, Linkedin, Twitter, etc A wide selection of journals (inclusive of 9 subjects, more than 200 journals)

Providing a 24-hour high-quality service

User-friendly online submission system

Fair and swift peer-review system

Efficient typesetting and proofreading procedure

Display of the result of downloads and visits, as well as the number of cited articles

Maximum dissemination of your research work

Submit your manuscript at: http://papersubmission.scirp.org/ 